\title{
BIOLOGICAL RISKS OF USING NON-THERMAL NON-IONIZING ELECTROMAGNETIC FIELDS
}

\author{
O.I. Nizhelska ${ }^{1}$, L.V. Marynchenko ${ }^{2^{*}}$, V.I. Piasetskyi ${ }^{3}$ \\ ${ }^{1}$ The Scientific and Training Center "Physical and Chemical Material Science", NAS of Ukraine, Kyiv, Ukraine \\ ${ }^{2}$ Igor Sikorsky Kyiv Polytechnic Institute, Kyiv, Ukraine \\ ${ }^{3}$ Private clinic "Viva", Kyiv, Ukraine \\ *Corresponding author: lolitamar@ukr.net
}

Received 24 January 2020; Accepted 20 March 2020

\begin{abstract}
Electromagnetic pollution of the environment has become a significant environmental factor. The intensity of technogenic electromagnetic fields far exceeds the background indicators to which organisms have adapted in the course of evolution, in particular by their biorhythms. Much data on the biological effects of lowintensity (non-thermal) extremely high-frequency electromagnetic fields (EHF-EMF) at different levels of the organization has been accumulated. There are many possible explanations for these impacts, but the mechanism of action is not established.

The purpose of this work is to analyze the negative effects of the use of non-thermal coherent electromagnetic radiation of extremely high frequencies. In particular, the use of microwave therapy is considered.

A review of reports on the harmful effects of non-ionizing electromagnetic and magnetic fields among the population and professional groups has been made; the presence of the problem of hypersensitivity to such fields was shown. Information on the development of the direction of study of the resonant biological influence of EHF-EMF by Ukrainian specialists was provided.

Particular attention is paid to the use of non-thermal microwaves for physiotherapy procedures, pain relief, correction of psycho-emotional disorders, ulcer healing, in particular stomach and duodenum, etc. It is noted that the so-called "therapeutic" frequencies of EHF-EMF, even if controlled, can cause negative effects, although they are not perceived as damaging. Changes in objective vital signs in the case of targeted exposure by low-intensity millimeter-wave radiation, namely, hemodynamics, temperature increase in the exposure zone, muscle activity, and the speed of the passage of a nerve impulse, an encephalogram were established. Precautionary recommendations based on the scientific and practical experience of using microwave acupuncture methods in the conditions of medical institutions are formulated.

The synergistic effect of various influences, in particular electromagnetic fields, may not be a direct trigger of the disease, but a factor of not compensated stress. Therefore, clinical studies conducted many years ago cannot simply be dismissed on the grounds that the millimeter radiation penetrates only the outer layer of the skin. Skin cells can also secrete mediators that cause changes in ionic calcium channels and the level of calcium in the cells. The interest in these works is justified by the fact that currently the sources of monochromatic millimeter radiation will be spread with new communication systems. The risks of their biological action should be taken into account when emitters are installed.
\end{abstract}

Keywords: technogenic electromagnetic radiation; biological effects; microwave therapy; biological risks.

\section{Introduction}

The problem of electromagnetic pollution of the environment has medical, economic, legal, technical, ecological, and cultural components. For many people, the danger of electromagnetic fields (EMF) being unregulated seems bizarre compared to the benefits of new technology. Unlike other scientific reviews, "old research" on this topic is relevant, as EMFs associated with new technologies do not replace previous influences but are constantly added to them. Therefore, it is necessary to take into account all available primary data to form the most complete picture of the action of nonionizing EMFs.
The purpose of our review was to analyze important, in our opinion, data relating to studies of the biological impact of EMF, including the experience of Ukrainian researchers, which is not represented in electronic digital databases and may, therefore, be lost, in view of the increasing proliferation of non-thermal non-ionizing EMFs.

\section{Characteristics of electromagnetic fields}

The electromagnetic radiation (EMR) spectrum includes waves from extremely low frequencies (with very long wavelengths) to very high ones (respectively, short wavelengths). Ionizing radiation starts from hard ultraviolet (wavelengths less than 
$100 \mathrm{~nm}$ ) and reaches X-rays and gamma rays [1]. The biological risk of high levels of ionizing radiation, which is capable of directly destroying tissues causing mutations and cancer, is already well known.

The part of the non-ionizing radiation spectrum from $3 \mathrm{kHz}$ to $3000 \mathrm{GHz}$ is defined as the radio frequency range. Visible light, infrared radiation, and soft ultraviolet are essential to the existence of life. A variety of photochemical reactions in living organisms provide the assimilation of solar energy and obtaining information about the environment. There are receptors for the perception of thermal radiation and electromagnetic waves of the visible spectrum, even in the simplest organisms. The presence of thermoreceptors is an important evolutionarily ancient mechanism for the adaptation of living things, in particular to the thermal component of electromagnetic radiation, which is a significant factor in natural biochemical processes but can potentially cause harm.

According to the Planck formula at $+37^{\circ} \mathrm{C}$, the surface of the body emits approximately $10 \mathrm{~mW}$ of $1 \mathrm{~cm}^{2}$ throughout the spectral range. Therefore, a power density of $10 \mathrm{~mW} / \mathrm{cm}^{2}$ is assumed to characterize the effect of electromagnetic radiation on biological objects as a thermal threshold. Nonionizing radiation with lower power density is considered to be non-thermal (weak). Non-thermal EMFs are also rated to be those that do not cause ambient heating above $0.1^{\circ} \mathrm{C}$, which falls within thermal noise. If the energy of the quantum of radiation $h v<k T$ ("kT problem") is mainly for lowfrequency radiation at ordinary temperatures ( $T$ about $300 \mathrm{~K}$ ), then this effect is weak in terms of energy but not null. Then there is the problem of detecting this effect among thermal fluctuations [2].

Natural EMF is considered by modern science to be one of the most important environmental factors, in particular chronoastrobiology. The Earth, the ionosphere, and the lower atmosphere form the global electrical circuit in which we live. It is well known that biological rhythms of humans, birds, insects are formed under the influence of the planet's natural electromagnetic environment, and the normal life of all organisms depends on the stability of the environment, including its electromagnetic properties. Natural origin EMFs are required for a normal life, in particular the formation of the circadian system, and their artificial increase or deficiency leads to a number of negative disorders [3-5].

Therefore, it is advisable to compare the technogenic EMF with the magnitude of the oscillations of natural (background) EMF to which living organisms are evolutionarily accustomed and by which biorhythms and relationships are formed at all levels of biological systems functioning: from macromolecules to populations and biocenoses. For example, the Earth's magnetic field at various points ranges from 20 to $65 \mu \mathrm{T}$, the magnetic field inside modern living space is $0.1 \mathrm{mT}$, and the field of permanent magnets is $0.1-1 \mathrm{~T}$ [6].

In modern cities, the spectral composition of electromagnetic noise almost overlaps the spectra of all known natural signals, and the intensity of technogenic EMFs sometimes exceeds the background of natural fields by orders of magnitude. This is exactly the connection in the microwave range that is developing most rapidly.

Microwaves are electromagnetic vibrations with a frequency from $300 \mathrm{MHz}$ to $300 \mathrm{GHz}$ (wavelength from several meters to a millimeter). The first microwave sources were constructed during the Second World War (the use of radars was based on the ability of microwaves to reflect off the metal shells of aircraft). Later, it was discovered that microwave radiation can accelerate various chemical reactions tens and hundreds of times; cause rapid volumetric heating of liquid and solid samples; effectively (quickly and completely) remove moisture from solid, including porous, materials; modify the properties of various sorbents. Especially significant absorption of microwave radiation (MR) is observed in water and aqueous solutions [7]. Thus, living cells fall into the highest risk zone when interacting with MR. For the human body, all the power of MR will be absorbed in the skin, eyes, cornea, blood vessels, and organs the most saturated with water. In this case, millimeterthick clothing can even enhance the absorption of incident microwaves, like an "anti-reflective coating" in optical devices. In this case, the thickness of the order of millimeters slightly reduces the power, and clothing that fits tightly to the skin even increases the power transmission [8].

The energy of the quantum of radiation $h v$ in the millimeter range is less than the energy of thermal motion $k T$. Even for the wavelength $\lambda=$ $=1 \mathrm{~mm} h v=1,17 \cdot 10^{-3} \mathrm{eV}$, while at room temperature $k T=2,53 \cdot 10^{-2} \mathrm{eV}$. The quantum energy is substantially lower not only for electron transition energy $(1-20 \mathrm{eV})$ or activation energy $(0.2 \mathrm{eV})$ but also for the vibrational energy of molecules $\left(10^{-2}-\right.$ $\left.10^{-1} \mathrm{eV}\right)$ and energy hydrogen bonds $\left(2 \cdot 10^{-2}-\right.$ $10^{-1} \mathrm{eV}$ ). Below this energy quantum, there are, for example, the energy of rotation of molecules around bonds $\left(10^{-4}-10^{-6} \mathrm{eV}\right)$, the energy of Cooper pairs at superconductivity $\left(10^{-4}-10^{-6} \mathrm{eV}\right)$, and the 
magnetic energy ordering $\left(10^{-4}-10^{-8} \mathrm{eV}\right)$. From the above energy estimation of different processes, it follows that the EMF of the microwave can appreciably affect the viability only in multi-quantum processes that are characteristic of coherent oscillations $[9,10]$.

Usually, the impact of fields of different ranges is combined because providers operate at different frequencies, but in densely populated areas they set up their radio objects next to each other [11]. Also, the $50 \mathrm{~Hz}$ industrial frequency inverter is not always installed in home devices, such as in an electric kettle. Insufficient shielding (or unlocked doors) of a working $2.45 \mathrm{GHz}$ microwave oven also contributes to the overall "electromagnetic smog" of urban areas.

\section{Epidemiological studies. Diseases associated with long-term exposure of working and living con- ditions}

Statistics of health complaints related to occurrence and spread of EMF sources have attracted the attention of hygienists and epidemiologists since the mid-twentieth century. Since that time that high-frequency EMFs of artificial origin have become a part of working conditions in industries using induction heating of materials, in communication enterprises, in physiotherapy rooms, in laboratories of research institutes. Special attention was paid to the risks of radio frequency exposure with the spread of cellular communications, radars, and other measuring instruments [12-14].

In addition to diseases in humans, especially children [14-16], near antenna-emitters, the adverse effect extends to forests [17], plants, including agricultural (corn, rosé, peas, fenugreek, duckweed, tomato, onion, and mango plants) [18], ants [1923], bees [22-23], Drosophila [24], birds [25-27], animals [28-31]. Thus, electromagnetic pollution disrupts ecological equilibrium, causes extinction of insects, tree diseases, mutations of microorganisms and viruses, and adversely affects the health of the population.

It has been found that working under the influence of EMF of all frequency ranges can cause functional disorders of the nervous and cardiovascular systems, asthenic symptom complex. With increasing work experience, even under conditions of low-intensity EMF, clinical manifestations become more pronounced, there is accumulation of effects. Common symptoms are as follows: attention deficit disorder, headache, weakness, disability, chronic fatigue, dizziness, poor sleep, decreased potency, changes in electroencephalograms, limb tremor, instability of the pulse, instability of blood pressure, allergic reactions [32-34]. Prolonged exposure by maximum permissible radiation doses on the brain and receptors of the vestibular and visual analyzers when using a cellular telephone leads to changes in the electroencephalogram (alpha, beta 1, 2 and delta waves), in synaptic structures and signal transduction, energy metabolism, in particular metabolism ATP, in the synthesis of proteins in brain structures, reduction in the number and density of dendritic spines, etc. If the antenna is inside the car, the train, the plane, then the metal body becomes a resonator and there is a multiple amplification of the EMF due to reflection. The magnitude of cellular EMF is commensurate with those arising from the operation of radar stations, ultrahigh frequency (microwave) heating devices [35, 36]. An increase in perinatal mortality and preeclampsia of offspring conceived by servicemen after an acute period of radiation exposure was also reported compared with service in other vessels [37].

According to various data, from 1.5 to $13 \%$ of people have an increased sensitivity to EMF [38]. The status of electromagnetic hypersensitivity in humans (so-called electrosensitivity) may occur after prolonged work with electromagnetic fields, for example, for electronic equipment testers. Sometimes hypersensitivity occurs after medical examinations using $\mathrm{X}$-rays or magnetic fields. Scientific studies of this phenomenon (known as idiopathic environmental intolerance attributed to electromagnetic fields (IEI-EMF)) have demonstrated, above all, patients' bias in their symptoms, which were not confirmed in double-blind experiments. However, some isolated cases of people's hypersensitivity to EMF have been reported, and researchers in their findings emphasize the need for more thorough studies, except for facts that could lead to distortions of results [37, 38-40]. It should be noted that some physiological reactions and behavior changes under the influence of EMF are also found in animals [41], where self-suggestion is not a question.

Technogenic fields also affect various receptors of the body: skin, visual, auditory, olfactory, vestibular, mucous membranes. The brain perceived such signals as dryness, burning, itching, dizziness, nausea, noise, and ringing in the ears. Smell and vision are disturbed. This is not a disease, because after the removal of the EMF everything came back to normal. But with prolonged exposure, irreversible changes occur [42].

Depressive states of the psyche are widespread among workers in the industrial frequency zone 
and among the population living near high-voltage power lines. A correlation was found between the statistically significant increase in the number of suicides among people undergoing chronic MF with a frequency of $50 \mathrm{~Hz}$ and an intensity greater than $0.15 \mu \mathrm{T}$. There is evidence of high risk for gastrointestinal dysfunction (2.5 times), liver (2.3 times), and endocrine pathology for contingent of people living in the area of power lines [43].

The effects of EMF include the follows: increased glucose metabolism in volunteers' brain as a marker of brain activity [44], hearing loss and tinnitus [45], changes in stem cell development [46], cardiovascular disease and cancer [47], cognitive disorders [48], changes in brain cell morphology [49], abnormalities in DNA [50], memory and learning disorders [51], reproductive disorders [52], changes of embryonic development [53], neurological disorders [54, 55], obesity and diabetes [56], effects on children, including autism [57, 58], syndrome of hyperactivity and attention deficit [59] and asthma [60].

Confirmation of pathogenic impact of nonionizing electromagnetic and magnetic fields by means of statistical analysis in professional groups, model animal studies, and experience of electromagnetic therapy was provided in the monograph [41].

In 2011, the WHO/International Agency for Research on Cancer concluded that EMF in the range of $30 \mathrm{kHz}$ to $300 \mathrm{GHz}$ could have carcinogenic effects on humans (Group 2B) [61].

\section{Some laboratory (model) researches on cell cultures, plants and animals}

Experimental studies of the influence of coherent electromagnetic oscillations of extremely high and hyper-high frequencies (millimeter and submillimeter ranges) on the biological systems have begun at the Institute of Radio Electronics of the USSR Academy of Sciences (Moscow), the Institute of Radiophysics and Electronics of the Ukrainian Academy of Sciences in the 1960's [62]. The first official scientific reports on the biological effects of millimeter-range EMR on biological objects of various levels of organization: viruses, microorganisms, insects, chicken embryos, rats and mice were presented by Zalyubovskaya and Devyatkov in 1973 at the Scientific Session of the Department of General Physics and Astronomy almost simultaneously [63].

Paying tribute to the enthusiasm of the pioneers - the scientific team led by academician Devyatkov, which became the methodological center of a new scientific direction, it is necessary to note the great contribution of Ukrainian science to the process of origin and formation of the problem of scientific substantiation of interactions of EMF with biological systems. Works of Zalyubovskaya, by its originality and depth of scientific decisions, were, at that time, ahead of the experimental substantiation of the researches of Devyatkov's group. And such works as the influence of EMR on the state of bioenergetic processes in animal organisms, the impact of EMR on the infectious activity of viral nucleic acids, principles, and criteria for evaluating the effects of millimeterrange EMF on biological objects today, by right, must be considered pioneer [64-67].

In the paper [68], it is shown the dependence of the ability of E. coli bacteria to synthesize colicin on the frequency and power level of EMF. It was found that irradiation at a wavelength of $6.5 \mathrm{~mm}$ for $2 \mathrm{~h}$ at a power flux density of about $5 \mu \mathrm{W} / \mathrm{cm}^{2}$ can change the proportion of microorganisms 2 to 3 times, that produce protein colicin. Later, the similar frequency dependence of yeast growth rate was confirmed in Germany by Grundler and Keilmann [69], and in Ukraine by the Andreyev's group [70]. It was shown that biological response depends, in addition to EMF parameters, on the method of preparation and the state of cell culture. The danger is that antibiotic resistance of the cultures of L. monocytogenes and E. coli is detected after exposure to $900 \mathrm{MHz}$ of GSM mobile radiation and $2.4 \mathrm{GHz}$ of radiofrequency radiation used by conventional Wi-Fi routers [71].

After the first scientific publications on the use of extremely high-frequency EMF (EHF-EMF) in biomedical research, which became the beginning of a new scientific direction, many original works were performed [72-77]. The presence of narrow frequency bands, which are close to the natural frequencies of individual organs or systems of the body (brain, heart, and circulatory system) both in the low-frequency (from 0 to $100 \mathrm{~Hz}$ ) and in the microwave ranges (for objects such as DNA, cell membranes, blood ions) was experimentally shown [78-80]. These results suggest the "resonant nature" of the low-intensity EMF influence. Therefore, the coincidence of the frequency of the external field and the natural frequencies of the object plays an important role.

Further studies intended to explain the mechanism of EHF-EMF action (at the power density of $18.6 \mathrm{~kW} / \mathrm{m}^{2}$ ) at the cellular level compared to thermal influences. For this purpose, a culture of murine neuronal cells derived from stem embryonic 
cells was used. The increase in $\mathrm{Ca}^{2+}$ fluctuations due to changes in N-type calcium channels with the participation of the phospholipase enzyme and the actin cytoskeleton (the latter also responsible for cellular biomechanics) was shown. Also, the production of nitric oxide was not reproduced only by thermal heating up to $42{ }^{\circ} \mathrm{C}$, although under the influence of $94 \mathrm{GHz}$ the heating in the chamber was only about $8^{\circ} \mathrm{C}[81]$.

A possible course of microwave irradiation action at the organism level was investigated. The simulated effect of the $30 \mathrm{~mW}$ EMF $94 \mathrm{GHz}$ on a $3 \mathrm{D}$ culture of two major skin components, keratinocytes and neuronal cells separated by $200 \mu \mathrm{m}$, showed a 5-fold secretion of neurotransmitters such as ATP molecules by keratinocytes and increased calcium spiking in neurons. It was shown that blocking ATP channels of keratinocytes in the case of increasing the power to $60 \mathrm{~mW}$ impeded the penetration of calcium into neurons, but was restored by the addition of ATP from the outside. This may explain the mechanism of activation of the central nervous system and the effect on the whole organism by the action of EHF-EMF on the epidermis mediated by ATP [82]. We consider this study important because the main objection to the potential biological risks of using EHF-EMF is its low permeability through the skin and, therefore, its inability to seriously affect human health.

In the case of frequency resonance, the EMF energy is effectively perceived by the object and may lead to restructuring of its structure and properties. It was described both theoretical and experimental determination of resonant frequencies (from molecules to the whole organism), which is the basis for establishing the primary receptors of biological action of weak EMFs [83-86].

A study of the effects of irradiation from mobile phones of different designs on the development of chicken embryos showed disturbance even at low doses ( $20 \mathrm{~min}$ per day), which, however, subsequently leveled off. Increased mortality by $14 \%$, limb deformity, skin disorders, weight loss and size reduction, fatty liver infiltration, increase in mitochondria, deformation and disappearance of cristae, increase in the level of heat shock protein Hsp 70 were observed at higher doses [87]. There was also a 2-3-fold increase in the duration of the incubation period due to the effect of EHF-EMF (especially when using a $6.5 \mathrm{~mm}$ wavelength) on the 7-day-old chicken embryo, although no deaths of the embryos were recorded. The weight of the obtained chickens from irradiated embryos did not differ from the controls until 7 days of life, but from 10-12 days to the end of the experiment (50 days) the weight gain was reduced [63].

In experiments on white rats of the Wistar line after 14 and 18 months of daily irradiation at a frequency of $970 \mathrm{MHz}$ for $2 \mathrm{~h}$, there was a statistical increase of the number of leukocytes and neutrophils by about 15 and $25 \%$, respectively, and a decrease of the number of lymphocytes by $15 \%$ compared with the group, which was fictitious. The increase in mortality after 21 months of irradiation at the age of 25 and especially 28 months was also convincing. The authors paid attention to the young age of the rats at which the study began (4 months) and supposed that young individuals are more vulnerable to such effects because their molecular mechanisms of compensation have been not generated enough [88].

It should be noted that, along with numerous reports of adverse effects of low-level radiation in the microwave range, there is considerable opposition to the recognition of hazards associated with the development of technology and facilities that accompany them. Substantial research is presented that denies any danger of radiation to biological objects and products [89-91] and the absence of reproduction of the declared effects. At the same time, these and other discussion problems of possible mechanisms of influence of EMF of megahertz, gigahertz, and terahertz bands are discussed in detail, for example, in the review [92].

\section{Attempts of medical using magnetic fields and extremely high-frequency electromagnetic fields}

An analysis of the available scientific publications makes it possible to identify two stages in the history of research into the effects of EMR on living organisms. This is the preclinical period (1966-1978) when the first experiments with microorganisms and animals were carried out, and the clinical period, when the obtained results became the basis for the limited clinical application of microwave EMF in medical practice $[72,93]$.

The first works on the effect of weak millimeter radiation on the human body were extremely difficult to publish. Neither official medicine nor official physics wanted to take responsibility and present results that "cannot be in existence". Also, the microwave range remained associated with the defense industry, and could be considered closed at any time. Therefore, to assume the primacy of articles in reputable scientific publications, or by names of academicians in co-authors, is not entirely correct: the administrators of further studies 
provided many publications and created their own thematic journals, securing the names of "Academician Devyatkov's group", "Professor Sit'ko's school".

The first studies were conducted when the background in the millimeter range was very low, many people really had not encountered microwave fields in their entire lives, the effect of this factor could be studied in its pure form and to observe the consequences. By now the situation is changing dramatically, now the millimeter narrowband radiation is being touted as a wonderful new type of communication that will soon cover the entire Earth. But the biological action is not mentioned. And no one, as a physician, will carefully select and control the therapeutic dose or determine the area of exposure of the microwave to the patient. It will become generalized. And the protection of health and safety will largely be determined by the level of human consciousness. This review provides information that may be a caveat when interacting with microwave radiation.

Interestingly, many of the first results were destructive: under the influence of the resonant frequency of EMF microwave bacteria of E. coli synthesized colicin, which killed them [68]; effects on chicken embryos and pregnant female rats caused developmental delays and birth defects [63]; decrease fertility [65]; "Rudenko's phenomenon" blocking the action of EMR by means of a magnetic field [94,95] - led to an increase in the ulcer defect in the patient. As a rule, health professionals tried to approach the patient carefully, remembering the main commandment - "do no harm", and physicists largely perceived the influence of EMF microwave as an experiment and considered as a valuable result even a negative strong effect on living organisms.

Subsequently, microwave therapy and its modifications (microwave resonance therapy, information wave therapy, microwave acupuncture) received technical support and distribution as a variant of wellness physiotherapy with not quite clear mechanisms of action, but relatively harmless compared to medical treatment. Attempts to build a theory, or at least a model of the resonant action of weak microwaves, on the basis of experimental data, have shown the enormous complexity of the interaction of a living organism with external electromagnetic radiation. This is still an open question too.

The Ukrainian direction of microwave therapy was developed in cooperation with specialists of reflexology (acupuncture). It has been shown that the needle introduced into the acupuncture point acts as an antenna, taking electromagnetic oscillations from the surrounding space and transmitting them to the corresponding "meridian" [96]. Thus, the millimeter radiation was similar to the needle, and the points of exposure were selected according to the rules of oriental acupuncture. The narrow resonant frequency band provided a powerful response of the organism at low radiation intensity. For various reasons, including some of the negative effects of such an impact, microwave reflexology is little used in Ukraine at this time. In Russia, from the very beginning, more attention has been paid to the hardware side - modulation, multi-frequency exposure, choice of modes, combinations with laser radiation. According to numerous works presented in the review [97], various microwave techniques are still used in medicine.

Theoretical and experimental studies have led to the emergence of a new method of electromagnetic therapy for the treatment of peptic ulcer of the stomach and duodenum, necrosis of the femoral head, manic-depressive psychosis, drug addiction (including smoking and alcoholism, for correction of vegetative nervous system functions), vegetative-vascular dystonias, complex rehabilitation of disabled persons suffering from limb defects, therapy of infantile cerebral palsy, wound processes, diabetes, early forms of cerebral vascular pathology, cerebral atherosclerosis, bronchial asthma, diseases of the lower extremities, diseases varicose veins for improving the efficiency of standard therapies used in oncology to restore the ability of cervical cancer patients to produce interferon after chemical therapy and others [98].

Western experts are skeptical about the possible effects of weak microwave fields on living organisms. The ambiguity of the mechanisms of influence, sometimes the opposite results from different researchers, the lack of a single test protocol, have led to respectable journals dismissing microwave action works as "unscientific". This has led to the fact that many of the original works of 30-40 years ago are unknown and not available throughout the Western world. Given that access to non-digitalized sources is now being lost and few professionals with unique years of experience remain, we are at risk of losing important information about the specificity of the effects of EHF-EMF on the human body, which was acquired under experimental clinical conditions, including by the authors.

The first reports on the therapeutic use of low-intensity microwaves were published in the early 1980s. From 1984 to 1994, practically all 
works related to the microwave effect on the human body were performed at the clinical hospital No. 3 in Kyiv. Medical results cited by Andreev, Bilyy and Sit'ko, Devyatkov and Golant, generally use the results of Klychniyazova and Piasetskyi with an attempt to justify the optimal modes of physical characteristics of external EMR and the localization of the area of influence in the treatment of a particular disease of man.

One of the first descriptions of the technique of the resonant effect of weak millimeter EMR on humans was published in the article [73]. 188 people, both healthy and ill by medical diagnostics, were tested. It has been found that in most cases healthy people do not respond to radiation in the range of $27-78 \mathrm{GHz}$ with a power density of up to $10 \mathrm{~mW} / \mathrm{cm}^{2}$. The same situation was typical for patients. However, local irradiation of certain areas of the body corresponding to acupuncture points (acupuncture) at fixed frequencies in the range of $45-65 \mathrm{GHz}$ caused a sensory response in patients with functional disorders. Sensory reactions caused by EMF were accompanied by significant changes in the physiological condition of the person: heart rate varied by $10-20$ beats per minute, blood pressure - by $10-15 \mathrm{~mm} \mathrm{Hg}$, effective renal plasma flow - by $10-20 \%$. Significant changes in the number of free radicals in saliva, fluctuations in acidity in the stomach, redness of the body, tremors of certain muscle groups, and hypnotic sleep were noted. Under influence of the frequencies, which correspond to the comfortable sensations of patients (reduction of pain, sensation of warmth, muscle relaxation, drowsiness), restores the functioning of diseased organs. The constancy of the frequency of many resonances over time in the case of chronic diseases, the individuality of the values of these frequencies for different organs, the small width of the resonance responses gave reason to call these frequencies their own characteristic frequencies of the human body.

The restructuring of the functional state of organs and systems spatially distant from the area of influence was accompanied by the occurrence of sensory reactions of local (paresthesia, coldness, heat, pain in the projection of the location of the "sick" organ) and generalized nature (excitation or suppression of psycho-emotional state, rhythmic contraction of the muscle group).

The rhythmic contraction of the group of muscles of the right and left thigh ("Rudenko's phenomenon") was registered during the treatment of peptic ulcer of the duodenum of the patient "R" by the method of microwave reflexology as a result of exposure by certain frequencies of EMF, which were aimed at biologically acupuncture points. Sharp dependence on frequency of EMF and degree of manifestation of muscle contraction made it possible to clearly visualize the resonant effect on the living organism. It was revealed that a magnetic field directed to certain areas of the skin surface blocks the information channel, which causes an appropriate response of the organism (rhythmic muscle contraction) to the influence of EMF. This phenomenon has been used by the authors [99] to detect the projection of these channels on the human body surface. The topography of the information channels found on the surface of the body practically coincides with the projection of the traditional meridians of acupuncture points used empirically in reflexology. Therapeutic methods of microwave therapy have been developed taking into account the notion that the areas of the surface of the body, which are most sensitive to EMF, coincide with the zones of acupuncture, zones of Zakharin-Ged [73, 74, 100].

The technique of sensory indication of frequency changes of external EMR of the millimeter range was applied in order to substantiate the possible "therapeutic" efficacy of one or another frequency of EMR [94]. The analysis of 300 patients with peptic ulcer of the stomach and duodenum, which were treated by the method of local influence on the reflexogenic areas of EMF of the microwave range, was in the surgical department of the clinical hospital No. 3 in Kyiv in the period 1984-1988 [101]. Treatment was carried out in a hospital setting, without the use of medication. Ulcerative history of $60 \%$ of patients was more than 5 years. The vast majority of patients are patients with peptic ulcer of the duodenum. The diameter of the ulcer defect of the gastric mucosa and duodenum was from 5 to $30 \mathrm{~mm}$. After treatment of the uncomplicated form of a peptic ulcer in the conditions of a hospital and appointment of the appropriate diet the subjective signs of the disease quickly disappeared, and patients, as a rule, were discharged with considerable improvement. In view of this, the effectiveness of treatment was evaluated by the healing of peptic ulcer (according to the results of gastroscopy), which, on the one hand, eliminated the element of subjectivism in the evaluation of results, on the other hand, made it possible to judge the effectiveness of microwave therapy.

The individual therapeutic frequency of external microwave EMF for patients with peptic ulcer disease was determined by the onset of sensory 
responses (pain relief, feeling of heat in the epigastric region, comfortable state). The studies were conducted in a chamber protected from environmental EMFs in terms of social and daily comfort. Generators operating on the Gunn diode, an avalanche diode, a backward wave tube, klystron generators in the frequency range of an EMF of 30-80 GHz were used as sources of EMR.

According to the distribution of the total number of patients, depending on their individual therapeutic frequencies of the external EMR, a chart was obtained indicating the presence of a narrow (about $\pm 3.5 \%$ ) of the frequency band in which the effect on physiological processes was most likely. The "healing" frequency of $61.5 \pm 2.5 \mathrm{GHz}$, thus found, is the basis for the development of "EHF Electronics" devices with the subsequent permission of the Ministry of Health of the USSR for mass production [100, 101].

An important condition for the use of microwaves in medicine is feedback to correct radiation parameters and duration of its action for a particular person. This is the only way to reduce the harmful effects. In addition to interviewing patients about their well-being, in the late 1980's - early 1990's the Saturn Research Institute together with the clinical site of the A. Shalimov Kyiv National Institute of Surgery and Transplantology methodologically developed and created an installation that allowed to record in real time physiological reactions in patients during microwave exposure directly in the impact zone (acupuncture points or reflex zones), physiological changes at the regional level, CNS response and directly state of the target organ (stomach, 12 duodenum). The temperature range $(\Delta T)$ compared to the non-irradiated area, the level of microhemodynamics (by laser Doppler), the rate of oxygen utilization by cells (transcutaneous polarography), and the absorption rate of EMR (calculated by the coefficient of standing wave factor) were evaluated in the area of influence.

Hemodynamics (by ultrasound Doppler ultrasound and plethysmography), the degree of muscle activity and the rate of passage of nerve impulse along the motor and sensory nerves (by myography) were investigated at the regional level, the state of CNS functioning in separate frequency ranges of the electroencephalogram in Fourier analysis and 12 duodenal ulcers were evaluated by electrogastrography and pH-metry at the central level [102].

Each individual result obtained from years of research conducted by one of the authors of this review deserves a separate publication, with further detailed analysis and discussion. As a summary of everything done, we can draw the following conclusions.

1) The duration of one microwave exposure procedure should not exceed 15-30 minutes. Already by $10-15$ minutes of microwave exposure with individually selected frequency recorded the maximum absorption of EMR. Levels of increased microcirculation and rate of metabolic processes caused by microwave exposure were maintained for one hour after the onset of direct exposure to EMF.

2) Normalization of indicators of a physiological state of a stomach and a 12 duodenal ulcer was observed at the main number of subjects to 5 sessions of microwave therapy and to 10 sessions in patients with a positive result of treatment (complete scarring of gastric ulcer or 12 duodenal ulcer).

3) The number of courses of microwave therapy should not exceed 2-3 during the year; otherwise, patients had the so-called subjectively unjustified microwave dependence.

Auricular (located on the ear) points for the effect of EMR on the human body were also used in the 1980's, before the proliferation of mobile phones, and physicians were careful because the ears have had a high density of reflex zones. At this time, the risks of such impact are hardly mentioned.

Therefore, microwave therapy, which can be a tool for regulating the functions of the human body, requires a highly qualified and experienced physician. Trying to influence the symptoms of a particular disease can cause imbalances in other systems. Even comfortable sensations during the action of the microwave field can cause addiction, such as narcotics, which is not positive.

The researches related to the possibility of microwave influence to change the emotional state of patients and the presence of frequencies of EMF capable of introducing of subjects to the trance state have acquired the status of certain alertness. Later, in the work of the Saturn Interdepartmental Laboratory, data were obtained indicating the effect of certain EMR frequencies on the low-frequency region of electroencephalograms of patients. These frequencies range from 150 to $300 \mathrm{GHz}$. In the future, the number of studies in this area was sharply limited for objective and subjective reasons.

Similar recommendations were given in [41]: microwave therapy should be used with extreme caution about children and persons of reproductive age; self-medication is strictly forbidden. Optimal 
and safe is the influence of microwave radiation not more than 2-5 minutes. In general, various methods of electro- and magnetotherapy have been described, for example [103-105]. The question of what will happen to those subjects who have been under the influence of sub-threshold (allowed) doses of the millimeter-wide EMR for a long time remains open. However, if there is stimulation of the reparative processes of the target organs of the microwave influence, changes in emotional states (drowsiness, analgesic effects), then these physiological reactions can in the future have negative consequences. There is a negative personal experience of people who have been closely involved in the development and implementation of millimeter-range EMF generating equipment, and of researchers who have experimented with these fields. Unfortunately, many lives ended with cancer and mental disorders, which, of course, was not advertised.

The most dangerous EMR frequencies for humans are in the range of 150 to $300 \mathrm{GHz}$. At present, there are no devices in such electromagnetic environment that generate such frequencies, but the experts know the phenomena of "harmonization of frequencies" of EMR, and this is extremely dangerous for the population, especially in the case of the introduction into a new practice of new communication systems.

Therefore, patient and medical safety issues related to Magnetic Resonance Imaging and Transcranial Magnetic Stimulation diagnosis are discussed in the light of the recommendations of the International Commission on Non-Ionizing Radiation Protection (ICNIRP) and the European Union EMF Directive (Directive 2013/35/EU) [106].

The synergism of various impacts is also discussed, in particular, EMF is considered not as a direct trigger of morbidity, but a stress factor [107], and this is extremely dangerous for the population, especially in the case of the introduction of new communication systems into wide practice.

A recent publication [108] emphasizes about the unconscious risks of using $5 \mathrm{G}$ technologies, warns that experiments conducted in the USSR cannot be simply discarded, and 5G technologies cannot be considered safe simply because the highfrequency EMF energy is weak and cannot penetrate deeper than the outer layer of skin. It is noted that the ICNIRP non-governmental private group is fulfilling the EU's radiation guidelines, rejecting any reservations about the potential biological risks of large-scale use of EHF-EMF.

\section{Conclusions}

In the course of evolution, living organisms have adapted to the natural levels and variations of non-ionizing EMFs. Purposeful studies of the biological effects of EMF with control of frequency, power, and other field characteristics have become possible, with the development of artificial sources of radiation in the microwave range. The results of studies conducted 50 years ago do not contradict current data on the biological effects of non-ionizing EMR. The advantages of the first experiments include a much lower level of background EMR than it is now, i.e. a greater "purity of control".

In many years of research into the biological effects of EHF-EMF, statistically, the most likely narrow frequency bands have been found for a therapeutic and regulatory effect on the body of patients with a particular disease, as confirmed by many clinical analyzes. A particularly significant reaction was observed with the effect of EMF on biologically active (reflexogenic) areas of the body surface. Microwave therapy equipment and techniques have been developed, based on these "healing" frequencies. However, it is reported that even exceeding "healing" frequency can cause negative consequences for the irradiated organism and its progeny. With the development of technology, studies have shown a large range of changes that occur when exposed to EMF in living cells and in the body as a whole. Therefore, persons working with microwave equipment or undergoing chronic exposure to even permitted doses of radiation should pay attention to these warnings, and the introduction of new technical means requires more careful research and means to reduce the biological risks of non-thermal non-ionizing EMF.

Biological risks of non-thermal EMF in humans can be conditionally structured as follows: 1) dramatic changes in indicators of life, behavior, deterioration of health directly during or within a few hours after the effect of EMF. They are observed in the case of exposure in the narrow frequency range to the vulnerable system of the body, to the biologically active zones; the most sensitive are people with health problems; 2) changes in metabolism, dependence on irradiation with therapeutic frequencies of EMF, weakening of immunity, impaired self-regulation, and disorders in nervous activity during prolonged chronic exposure to non-thermal EMF. These risks can be minimized by controlling your own duration of location in the 
radiation area; 3) increased risk of genetic alterations in offspring after parental irradiation. Therefore, persons working with microwave equipment or undergoing chronic exposure to even permitted doses of radiation should pay attention to these warnings, and the introduction of new technical means requires more careful research and means to reduce the biological risks of using non-thermal non-ionizing electromagnetic fields.

\section{References}

[1] Cleveland RF, Ulcek JL. Questions and answers about biological effects and potential hazards of radiofrequency electromagnetic fields [Internet]. Transition.fcc.gov. 2019 [cited 2019 May 25].

Available from: https://transition.fcc.gov/Bureaus/Engineering_Technology/Documents/bulletins/oet56/oet5

[2] Bingi V, Savin A. Effects of weak magnetic fields on biological systems: physical aspects. Physics-Uspekhi. 2003 Mar 31;46(3):259-91. DOI: 10.1070/PU2003v046n03ABEH001283

[3] Halberg F, Cornelissen-Guillaume GG, Otsuka K, Watanabe Y, Katinas GS, Burioka N, et al. Cross-spectrally coherent $\sim 10.5$ - and 21-year biological and physical cycles, magnetic storms and myocardial infarctions. Neuroendocrinol Lett. 2000 Jan 1;21(3):233-58.

[4] Martyinyuk VS, Vladimirskiy BM, Temuryants NA. Biological rhythms and electromagnetic fields of the environment. Geofizicheskie Protsessyi i Biosfera. 2006;5(1):5-23.

[5] Lewczuk B, Redlarski G, Żak A, Ziółkowska N, Przybylska-Gornowicz B, Krawczuk M. Influence of electric, magnetic, and electromagnetic fields on the circadian system: current stage of knowledge. BioMed Res Int. 2014;2014:1-13. DOI: $10.1155 / 2014 / 169459$

[6] Zhang X, Yarema K, Xu A. Biological Effects of Static Magnetic Fields. Singapore: Springer; 2017. 220 p. DOI: 10.1007/978-981-10-3579-1

[7] Berdonosov SS. Microwave chemistry. Sorovskiy Obrazovatelnyiy Zhurnal. 2001;7(1):32-8.

[8] Gandhi O, Riazi A. Absorption of millimeter waves by human beings and its biological implications. IEEE Trans Microw Theory Tech. 1986 Mar;34(2):228-35. DOI: 10.1109/TMTT.1986.1133316

[9] Fröhlich H. Long-range coherence and energy storage in biological systems. Int J Quantum Chem. 1968 Sep;2(5):641-9. DOI: $10.1002 /$ qua.560020505

[10] Fröhlich H. Bose condensation of strongly excited longitudinal electric modes. Phys Lett A. 1968 Mar 25;26(9):402-3. DOI: 10.1016/0375-9601(68)90242-9

[11] Mazurek PA, Naumchuk OM, Kot K, Wdowiak A, Zybała M. Exposure of high frequency electromagnetic fields in the living environment. EJMT. 2018 Oct 30;4(21):33-9.

[12] Bandara P, Weller S. Cardiovascular disease: Time to identify emerging environmental risk factors. Eur J Prevent Cardiol. 2017 Oct; 24(17):1819-23. DOI: 10.1177/2047487317734898

[13] Habash RWY, Brodsky LM, Leiss W, Krewski D, Repacholi M. Health risks of electromagnetic fields. Part II: Evaluation and assessment of radio frequency radiation. Crit Rev Biomed Eng. 2003;31(3):1-58. DOI: 10.1615/CritRevBiomedEng.v31.i3.20

[14] Hardell L, Sage C. Biological effects from electromagnetic field exposure and public exposure standards. Biomed Pharmacother. 2008 Feb;62(2):104-9. DOI: 10.1016/j.biopha.2007.12.004

[15] Sage C, Carpenter DO. Public health implications of wireless technologies. Pathophysiology. 2009;16(2-3):233-46. DOI: 10.1016/j.pathophys.2009.01.011

[16] Hardell L, Carlberg C. Mobile phones, cordless phones and the risk for brain tumors. Int J Oncol. 2009 Jul;35(1):5-17. DOI: 10.3892/ijo_00000307

[17] Waldmann-Selsam C, Balmori-de la Puente A, Breunig H, Balmori A. Radiofrequency radiation injures trees around mobile phone base stations. Sci Total Environ. 2016 Dec;572:554-69. DOI: 10.1016/j.scitotenv.2016.08.045

[18] Halgamuge MN. Review: Weak radiofrequency radiation exposure from mobile phone radiation on plants. Electromagn Biol Med, 2017 Sep;36(2):213-35. DOI:10.1080/15368378.2016.1220389

[19] Warnke U. Bees, birds and mankind. Destroying nature by 'Electrosmog': effects of wireless communication technologies [Internet]. Media.withtank.com. 2019 [cited 2019 May 25]. Available from: http://media.withtank.com/4a1515f54f.pdf

[20] Balmori A. Electromagnetic pollution from phone masts. Effects on wildlife. Pathophysiology. 2009 Aug;16(2-3):191-9. DOI: 10.1016/j.pathophys.2009.01.007

[21] Cammaerts MC, Johansson O. Ants can be used as bio-indicators to reveal biological effects of electromagnetic waves from some wireless apparatus. Electromagn Biol Med. 2013 Aug;33(4):282-8. DOI: 10.3109/15368378.2013.817336

[22] Kumar NR, Sangwan S, Badotra P. Exposure to cell phone radiations produces biochemical changes in worker honey bees. Toxicol Int. 2011 Jan-Jun;18(1):62-6. DOI: 10.4103/0971-6580.75869 
[23] Balmori A. Efectos de las radiaciones electromagnéticas de la telefonía móvil sobre los insectos. Ecosistemas. 2006;15(1):87-95.

[24] Margaritis LH, Manta AK, Kokkaliaris KD, Schiza D, Alimisis K, Barkas G, et al. Drosophila oogenesis as a bio-marker responding to EMF sources. Electromagn Biol Med. 2014 Aug;33(3):165-89. DOI: 10.3109/15368378.2013.800102

[25] Broomhall M. Report detailing the exodus of species from the Mt. Nardi area of the Nightcap National Park World Heritage Area during a 15-year period (2000-2015) [Internet]. Emraware.com. 2019 [cited 2019 May 25]. Available from: http://emraware.com/Documents/Mt\%20Nardi\%20Wildlife\%20Report\%20to\%20UNESCO.pdf

[26] Balmori A. Possible effects of electromagnetic fields from phone masts on a population of white stork (Ciconia ciconia). Electromagn Biol Med. 2005 Jan;24(2):109-19. DOI: 10.1080/15368370500205472

[27] Kordas D. Birds and trees of Northern Greece: Changes since the advent of 4G wireless [Internet]. Einarflydal.files.wordpress.com. 2019 [cited 2019 May 25].

Available from: https://einarflydal.files.wordpress.com/2017/08/kordas-birds-and-trees-of-northern-greece-2017-final.pdf

[28] Balmori A. Mobile phone mast effects on common frog (Rana temporaria) tadpoles: The city turned into a laboratory. Electromagn Biol Med. 2010 Jan;29(1-12):31-5. DOI: 10.3109/15368371003685363

[29] Balmori A. The incidence of electromagnetic pollution on wild mammals: A new "poison" with a slow effect on nature? Environmentalist. 2010 Mar;30(1):90-7. DOI: 10.1007/s10669-009-9248-y

[30] Magras IN, Xenos TD. RF radiation-induced changes in the prenatal development of mice. Bioelectromagnetics. 1997;18(6):455-61. DOI: 10.1002/(sici)1521-186x(1997)18:6<455::aid-bem8>3.0.co;2-1

[31] Otitoloju AA, Osunkalu VO, Oduware R, Obe IA, Adewale AO. Haematological effects of radiofrequency radiation from GSM base stations on four successive generations (F1-F4) of albino mice, Mus Musculus. J Environ Occup Sci. 2012;1(1):17-22. DOI: $10.5455 /$ jeos.20120602121540

[32] Ahlbom A, Green A, Kheifets L, Savitz D, Swerdlow A. Epidemiology of health effects of radiofrequency exposure. Environ Health Perspect. 2004 Dec;112(17):1741-54. DOI: 10.1289/ehp.7306

[33] Saunders R, Croft RJ, van Rongen E. Biological effects and health consequences of ELF and RF fields. Comprehens Biomed Phys. 2014 Aug;7:323-53. DOI: 10.1016/B978-0-444-53632-7.00816-9

[34] Tomashevskaya LA, Kravchun TE, Lemeshko LP, Didyk NV, Bezverha AP. For the question of biological effects electromagnetic pollution. Hihiyena Naselenyh Mists. 2013;62:193-9.

[35] Zhi WJ, Wang LF, Hu XJ. Recent advances in the effects of microwave radiation on brains. Military Med Res. 2017 Sep;4(1):29. DOI: 10.1186/s40779-017-0139-0

[36] Grigorev YG, Grigorev KA. The electromagnetic fields of the base stations of the mobile radio communication and ecology. The estimation of danger of the base station EMF for population and for bioecosystems. Radiation Biol Radioecol. 2005;45(6):726-31.

[37] Baste V, Moen BE, Oftedal G, Strand LÅ, Bjørge L, Mild KH. Pregnancy outcomes after paternal radiofrequency field exposure aboard fast patrol boats. J Occupat Environ Medicine. 2012 Apr;54(4):431-8. DOI: 10.1097/JOM.0b013e3182445003

[38] Hillert L, Berglind N, Arnetz BB, Bellander T. Prevalence of self-reported hypersensitivity to electric or magnetic fields in a population-based questionnaire survey. Scand J Work Environ Health. 2002 Feb;28(1):33-41. DOI: 10.5271/sjweh.644

[39] Rubin GJ, Hillert L, Nieto-Hernandez R, van Rongen E, Oftedal G. Do people with idiopathic environmental intolerance attributed to electromagnetic fields display physiological effects when exposed to electromagnetic fields? A systematic review of provocation studies. Bioelectromagnetics. 2011 Jul;32(8):593-609. DOI: 10.1002/bem.20690

[40] Bogers RP, Van Gils A, Clahsen SCS, Vercruijsse W, Van Kamp I, Baliatsas C, et al. Individual variation in temporal relationships between exposure to radiofrequency electromagnetic fields and non-specific physical symptoms: A new approach in studying 'electrosensitivity'. Environment Int. 2018 Dec;121(1):297-307. DOI: 10.1016/j.envint.2018.08.064

[41] Moskvin SV, Sokolovskaya LV, Subbotina TI, Hadartsev AA, Yashin AA, Yashin MA. Pathogenic effects of non-ionizing radiation on the human body. Moscow, Tver, Tula: Triada, 2007. 183 p.

[42] Betskiy OV, Yaremenko YG. Skin and electromagnetic waves. Millimetrovyie Volnyi v Biologii i Meditsine. 1998;1(11):3-15.

[43] Gurvich EB, Novohatskaya EA, Rubtsova NB. The mortality rate of the population living near a $500 \mathrm{kV}$ power transmission facility. Russian Journal of Occupational Health and Industrial Ecology. 1996;9:23-7.

[44] Volkow ND, Tomasi D, Wang G-J, Vaska P, Fowler JS, Telang F, et al. Effects of cell phone radiofrequency signal exposure on brain glucose metabolism. JAMA. 2011 Feb;305(8):808-13. DOI: 10.1001/jama.2011.186

[45] Medeiros LN, Sanchez TG. Tinnitus and cell phones: the role of electromagnetic radiofrequency radiation. Brazilian J Otorhinolaryngol. 2016 Feb;82(1):97-104. DOI: 10.1016/j.bjorl.2015.04.013

[46] Eghlidospour M, Ghanbari A, Mortazavi SMJ, Azari H. Effects of radiofrequency exposure emitted from a GSM mobile phone on proliferation, differentiation, and apoptosis of neural stem cells. Anatomy Cell Biol. 2017 Jun;50(2):115-23. DOI: $10.5115 / \mathrm{acb} \cdot 2017.50 .2 .115$ 
[47] Bandara P, Weller S. Cardiovascular disease: Time to identify emerging environmental risk factors. Europ J Prevent Cardiol. 2017 Nov;24(17):1819-23. DOI: 10.1177/2047487317734898

[48] Deshmukh P, Nasare N, Megha K, Banerjee BD, Ahmed RS, Singh D, et al. Cognitive impairment and neurogenotoxic effects in rats exposed to low-intensity microwave radiation. Int J Toxicol. 2015 Mar;34(3):284-90. DOI: 10.1177/1091581815574348

[49] Belokrinitskiy VS. Changes in brain cells during prolonged exposure to microwave radiation of low intensities $(50,25,10$, $5 \mu \mathrm{W} / \mathrm{cm}^{2}$ ) and their significance for the body. Hihiyena Naselenyh Mists. 2006;48:224-31.

[50] Zothansiama, Zosangzuali M, Lalramdinpuii M, Jagetia GC. Impact of radiofrequency radiation on DNA damage and antioxidants in peripheral blood lymphocytes of humans residing in the vicinity of mobile phone base stations. Electromag Biol Med. 2017 Aug;36(3):295-305. DOI: 10.1080/15368378.2017.1350584

[51] Narayanan SN, Kumar RS, Potu BK, Nayak S, Mailankot M. Spatial memory performance of Wistar rats exposed to mobile phone. Clinics. 2009;64(3):231-34. DOI: 10.1590/S1807-59322009000300014

[52] Houston BJ, Nixon B, King BV, de Iuliis GN, Aitken RJ. The effects of radiofrequency electromagnetic radiation on sperm function. Reproduction. 2016 Dec;152(6):R263-6. DOI: 10.1530/REP-16-0126

[53] Han J, Cao Z, Liu X, Zhang W, Zhang S. Effect of early pregnancy electromagnetic field exposure on embryo growth ceasing. Wei Sheng Yan Jiu. 2010 May;39(3):349-52.

[54] Salford LG, Brun AE, Eberhardt JL, Malmgren L, Persson BRR. Nerve cell damage in mammalian brain after exposure to microwaves from GSM mobile phones. Environ Health Perspect. 2003 Jun;111(7):881-3. DOI: 10.1289/ehp.6039

[55] Bilokrynytsky V. Microwave pathology of the brain as a result of SHF field influence. Visn Nac Akad Nauk Ukr. 2007(5):23-9.

[56] Milham S. Evidence that dirty electricity is causing the worldwide epidemics of obesity and diabetes. Electromagn Biol Med. 2014 Jun;33(1):75-8. DOI: 10.3109/15368378.2013.783853

[57] Herbert M, Sage C. Findings in autism (ASD) consistent with electromagnetic fields (EMF) and radiofrequency radiation (RFR). Bioiniative 2012. p. 1-106.

[58] Kane RC. A possible association between fetal/neonatal exposure to radiofrequency electromagnetic radiation and the increased incidence of autism spectrum disorders (ASD). Medical Hypotheses. 2004 Feb;62(2):195-7. DOI: 10.1016/S0306-9877(03)00309-8

[59] Divan HA, Kheifets L, Obel C, Olsen J. Cell phone use and behavioural problems in young children. J Epidemiol Community Health. 2010 Dec;66(6):524-9. DOI: 10.1136/jech.2010.115402

[60] Li D-K, Chen H, Odouli R. Maternal exposure to magnetic fields during pregnancy in relation to the risk of asthma in offspring. Arch Pediatr Adolesc Med. 2011 Aug;165(10):945-950. DOI:10.1001/archpediatrics.2011.135

[61] IARC classifies radiofrequency electromagnetic fields as possibly carcinogenic to humans. IARC Press Release. 2011 May;208:1-6.

[62] Golant MB, Vilenskaya RL, Zyulina EA, Kaplun ZF, Negirev AA, Parilov VA, et al. A series of wide-range low-power generators of millimeter and submillimeter wavelength ranges. Priboryi i Tehnika Eksperimenta. 1965;4:136-9.

[63] Zalyubovskaya NP. Reactions of living organisms to exposure to millimeter-band electromagnetic waves. Sov Phys Usp. 1973;110(7):462-4. DOI: 10.3367/UFNr.0110.197307r.0462

[64] Kiselev RI, Zalyubovskaya NP. Effects of millimeter-band electromagnetic waves in the cell and certain structural elements of the cell. Sov Phys Usp. 1974 Apr;16(4):576-7. DOI: 10.1070/PU1974v016n04ABEH005323

[65] Zalyubovskaya NP. Biological effect of millimeter radiowaves. Vrachebnoye Delo. 1977;3:116-9.

[66] Zalyubovskaya NP, Kiselev RI. Principles and criteria for assessing the effects of millimeter-wave electromagnetic fields on biological objects. Vesti HGU. 1975;130:138-41

[67] Zalyubovskaya NP, Kiselev RI. Biological oxidation in the cell under the action of millimeter-wave radio waves. Cytol Genetics. 1978;12(3):232-6.

[68] Smolyanskaya AZ, Vilenskaya RL. The effect of millimeter-wave electromagnetic radiation on the functional activity of certain genetic elements of bacterial cells. Sov Phys Usp. 1973;110(7):458-60. DOI: 10.3367/UFNr.0110.197307o.0458

[69] Grundler W, Keilmann F, Fröhlich H. Resonant growth rate response of yeast cells irradiated by weak microwaves. Phys Lett A. 1977 Sep;62:463-6. DOI: 10.1016/0375-9601(77)90696-X

[70] Andreev EA, Belyiy MU, Karachentseva AI, Kislaya LV, Marinchenko LV, Yakunov AV. Resonant response of yeast cells to the low-intensity electromagnetic field of the millimeter range. Izvestiya Vyisshih Uchebnyih Zavedeniy Pischevaya Tehnologiya. 1990;2-3:30-1.

[71] Taheri M, Mortazavi SM, Moradi M, Mansouri S, Hatam GR, Nouri F. Evaluation of the effect of radiofrequency radiation emitted from Wi-Fi router and mobile phone simulator on the antibacterial susceptibility of pathogenic bacteria Listeria monocytogenes and Escherichia coli. Dose-Response. 2017 Jan;15(1):1559325816688527. DOI: 10.1177/1559325816688527 
[72] Cherkassov IS, Nedzvetsky VA, Gilenko VA. Biomedical effects of millimeter-wave radio waves. Oftalmologicheskiy Zhurnal. 1978:3:187-90.

[73] Andreev EA, Belyiy MU, Sitko SP. Manifestation of characteristic frequencies of the human body. Dokladyi AN USSR Ser B. 1984;10:60-3.

[74] Andreev EA, Belyiy MU, Sitko SP. The reaction of the human body to electromagnetic radiation millimeter range. Vestnik AN SSSR. 1985;1:24-32.

[75] Michaelson SM. Microwave and radiofrequency radiation. ICP/CEP 808. Copenhagen: WHO - Regional Office for Europe; 1976. p. 1-98.

[76] Michaelson SM. Biological Effects and Health Hazards of RF and MW Energy: Fundamentals and Overall Phenomenology. In: Grandolfo M, Michaelson SM, Rindi A, editors. Biological effects and dosimetry of nonionizing radiation. NATO Advanced Study Institutes Series (Series A: Life Sciences), vol 49. Boston: Springer; 1983. DOI: 10.1007/978-1-4684-4253-3_15

[77] Keilmann F. Experimental RF and MW resonant nonthermal effects. In: Grandolfo M, Michaelson SM, Rindi A, editors. Biological effects and dosimetry of nonionizing radiation. NATO Advanced Study Institutes Series (Series A: Life Sciences), vol 49. Boston: Springer; 1983. DOI: 10.1007/978-1-4684-4253-3_12

[78] Keilmann F, Grundler W. Sharp resonances in yeast growth prove nonthermal sensitivity to microwaves. Phys Rev Lett. 1983 Sep;51(13):1214-6. DOI: 10.1103/PhysRevLett.51.1214

[79] Khabarova O, Dimitrova S. On the nature of people's reaction to space weather and meteorological weather changes. Sun Geosphere. 2009 Dec;4(2):60-71.

[80] Khabarova OV. Bioeffective frequencies and their coupling with own frequencies of alive organisms. Biomediczinskie tekhnologii i radioelektronika. 2002;5:56-66.

[81] Titushkin IA, Rao VS, Pickard WF, Moros EG, Shafirstein G, Cho MR. Altered calcium dynamics mediates P19-derived neuron-like cell responses to millimeter wave radiation. Radiat Res. 2009 Dec;172:725-36. DOI: 10.1667/RR1760.1

[82] Sun S, Titushkin I, Varner J, Cho M. Millimeter wave-induced modulation of calcium dynamics in an engineered skin co-culture model: role of secreted ATP on calcium spiking. J Radiat Res. 2012 Mar;53(2):159-67. DOI: 10.1269/jrr.11037

[83] Yang S, Lin H, Liu T, Lu J, Hung W, Huang Y, et al. Efficient structure resonance energy transfer from microwaves to confined acoustic vibrations in viruses. Sci Rep. 2005 Dec;5(1):1-10. DOI: 10.1038/srep18030

[84] Grundler W, Keilmann F, Putterlik V, Santo L, Strube D, Zimmermann I. Nonthermal Resonant Effects of $42 \mathrm{GHz}$ Microwaves on the Growth of Yeast Cultures. In: Fröhlich H, Kremer F, editors. Coherent Excitations in Biological Systems. Proceedings in Life Sciences. Berlin, Heidelberg: Springer; 1983. DOI: 10.1007/978-3-642-69186-7_4

[85] Binhi VN, Savin AV. Molecular gyroscopes and biological effects of weak ELF magnetic fields. Phys Rev E. 2002 May;65(5). DOI: 10.1103/PhysRevE.65.051912

[86] Binhi VN, Prato FS. Rotations of macromolecules affect nonspecific biological responses to magnetic fields. Sci Rep. 2018 Sep;8(1):13495. DOI: 10.1038/s41598-018-31847-y

[87] Siddiqi N, Al Nazwani N. Effects of electromagnetic field on the development of chick embryo: An in vivo study. In: Electromagnetic fields and waves. IntechOpen; 2019. DOI: 10.5772/intechopen.84704

[88] Adang D, Remacle C, Vander Vorst A. Results of a long-term low-level microwave exposure of rats. IEEE Trans Microw Theory Techn. 2009 Sep;57(10):2488-97. DOI: 10.1109/TMTT.2009.2029667

[89] Mortazavi SM, Mahbudi A, Atefi M, Bagheri S, Bahaedini N, Besharati A. An old issue and a new look: electromagnetic hypersensitivity caused by radiations emitted by GSM mobile phones. Technol Health Care. 2011 Jan;19(6):435-43. DOI: 10.3233/THC-2011-0641

[90] Uysal I, Hohberger C, Rasmussen RS, Ulrich DA, Emond JP, Gutierrez A. Effects of radio frequency identification-related radiation on in vitro biologics. PDA J Pharm Sci Technol. 2012 Jul;66(4):333-45. DOI: 10.5731/pdajpst.2012.00875

[91] Warille AA, Altun G, Elamin AA, Kaplan AA, Mohamed H, Yurt KK, et al. Skeptical approaches concerning the effect of exposure to electromagnetic fields on brain hormones and enzyme activities. J Microscopy Ultrastruct. 2017 Dec;5(4):177-84. DOI: $10.1016 /$ j.jmau.2017.09.002

[92] Romanenko S, Begley R, Harvey AR, Hool L, Wallace VP. The interaction between electromagnetic fields at megahertz, gigahertz and terahertz frequencies with cells, tissues and organisms: risks and potential. J Royal Soc Interf. 2017 Dec;14(137):20170585. DOI: 10.1098/rsif.2017.0585

[93] Devyatkov ND, Golant MB, Rebrova TB. On the possibility of using coherent electromagnetic information signals of living organisms for the diagnosis and treatment of diseases. Elektronnaya Tehnika Ser Elektronika SVCh. 1983;4(352):49-51.

[94] Klyichnyiyazova MM, Kutsenok VA, Pyasetskiy VI. EMF peptic ulcer treatment. In: Proccedings of the 1st All-Union Coordination Meeting on Sharing Experience in Using Low-Power Millimeter-Band EMR for Medical Grade. Moscow: IRE AN USSR; 1984. p. 18. 
[95] Andreev EA, Belyiy MU, Kutsenok VA, Levinets LS, Pyasetskiy VI, Sitko SP, et al. The physical basis of the microwave (bioresonance) correction of the physiological conditions of the human body. The use of millimeter radiation of low intensity in biology and medicine. Moscow; 1985. p. 58-83.

[96] Romadanov AP, Gostev VI, Lyaschenko DS, Kaydash IN. Antenna properties of Chinese acupuncture needles. Vrachebnoe Delo. 1984;8:93-7.

[97] Grachev VI, Kolesov VV. Methods and apparatus for EHF-puncture therapy. Radiolectron Nanosyst Inform Technol. 2009;1(1-2):171-194.

[98] Zemskov BC, Korpan HH, Hohlich YI, Pavlenko VA, Nazarenko LS, et al. The effect of low-intensity millimeter-wave electromagnetic radiation on wound healing. Klinicheskaya Hirurgiya. 1988;1:31-3.

[99] Gassanov LG, Pisanko OI, Pyasetskiy VI. The use of low-intensity electromagnetic EHF for the treatment of uncomplicated gastroduodenal ulcers. Electronic Industry. 1987;1:31-3.

[100] Gassanov LG, Pyasetskiy VI, Pisanko OI. The role of the environmental factor in the interaction of low-intensity electromagnetic fields of extremely high frequency with the human body. Visnyk of the NAS of Ukraine. 1988;10:33-8.

[101] Gassanov LG, Pisanko OI, Pyasetskiy VI. Devices "Electronics-EHF" and their use in biology and medicine. Kyiv: Znanie; 1990. p. 1-26.

[102] Pyasetskiy VI, Baharev AM, Pisanko OI, Kutsenok VA, Babichenko ME. Clinical and instrumental studies of physiological reactions in EHF-therapy of peptic ulcer. In: Devyatkov ND, Betskij OV, editors. Millimeter Waves in Medicine, vol. 1. Moscow; 1991. p. 16-31.

[103] Markov MS. Expanding use of pulsed electromagnetic field therapies. Electromagn Biol Med. 2007 Jan;26(3):257-74. DOI: $10.1080 / 15368370701580806$

[104] Consales C, Merla C, Marino C, Benassi B. Electromagnetic fields, oxidative stress, and neurodegeneration. Int J Cell Biol. 2012 Jun;19:1-16. DOI: 10.1155/2012/683897

[105] Markov M. XXIst century magnetotherapy. Electromagn Biol Med. 2015 Jul;34(3):190-6. DOI: 10.3109/15368378.2015.1077338

[106] Shigemitsu T, Ueno S. Biological and health effects of electromagnetic fields related to the operation of MRI/TMS. Spin. 2017 Dec;7(4):1740009. DOI: 10.1142/S2010324717400094

[107] Vořchuk SI. Saccharomyces cerevisiae as a model organism for studying the carcinogenicity of non-ionizing electromagnetic fields and radiation. Mikrobiolohichnyi Zhurnal 2014;76(1):53-61.

[108] Hardell L, Nyberg R. Appeals that matter or not on a moratorium on the deployment of the fifth generation, 5G, for microwave radiation. Mol Clin Oncol. 2020 Mar;12(3):247-57. DOI: 10.3892/mco.2020.1984

\section{О.І. Ніжельська, Л.В. Маринченко, В.І. Пясецький}

\section{БІОЛОГІЧНІ РИЗИКИ ЗАСТОСУВАННЯ НЕТЕПЛОВИХ НЕІОНІУУЮЧИХ ЕЛЕКТРОМАГНІТНИХ ПОЛІВ}

Електромагнітне забруднення навколишнього простору стало вагомим екологічним чинником. Інтенсивність техногенних електромагнітних полів значно перевищує фонові показники, до яких організми пристосувались у процесі еволюції, зокрема своїми біоритмами. Накопичено багато даних щодо біологічного впливу низькоінтенсивних (нетеплових) електромагнітних надвисокочастотних полів (ЕМП НВЧ) на різних рівнях організації. Існує багато можливих пояснень таких впливів, але механізм дії не встановлений.

Метою роботи $€$ аналіз негативних наслідків застосування нетеплового когерентного електромагнітного випромінювання надвисоких частот. Зокрема, розглянуто використання НВЧ-терапії.

Зроблено огляд повідомлень про згубні наслідки неіонізуючих електромагнітних і магнітних полів серед населення та професійних груп, показано наявність проблеми гіперчутливості до таких полів. Надано інформацію про розвиток напряму вивчення резонансного біологічного впливу НВЧ-випромінювання українськими фахівцями.

Особливу увагу приділено застосуванню ЕМП НВЧ нетеплової інтенсивності для фрізіотерапевтичних процедур, зняття больового синдрому, корекції психоемоційних порушень, загоєння виразок, зокрема шлунка та дванадцятипалої кишки тощо. Зазначено, що так звані “лікувальні" частоти у разі навіть контрольованого впливу можуть спричиняти негативні наслідки, хоча вони й не сприймаються як пошкоджувальні. Було відзначено зміни в разі цілеспрямованого впливу низькоінтенсивного випромінювання міліметрового діапазону об'єктивних показників життєдіяльності, а саме: гемодинаміки, підвищення температури у зоні впливу, м'язової активності та швидкості проходження нервового імпульсу, енцефалограми. Сформульовано застережливі рекомендації на основі науково-практичного досвіду застосування методів НВЧ-акупунктури в умовах лікувальних закладів.

Синергічна дія різних впливів, зокрема електромагнітних полів, може бути не безпосереднім тригером захворювання, а фактором нескомпенсованого стресу. Тому клінічні дослідження, проведені багато років тому, не можна просто відкинути на підставі того, що випромінювання міліметрового діапазону проникає лише у зовнішній шар шкіри. Клітини шкіри також можуть виділяти медіатори, що спричиняють зміни в іонних кальцієвих каналах та коливання рівня кальцію в клітинах.

Інтерес до цих робіт виправданий тим, що наразі джерела монохроматичного міліметрового випромінювання будуть поширюватися разом із новими системами зв'язку. Ризики їх біологічної дії мають бути враховані у разі встановлення випромінювачів.

Ключові слова: техногенне електромагнітне випромінювання; біологічний вплив; надвисокочастотна терапія; біологічні ризики. 


\section{БИОЛОГИЧЕСКИЕ РИСКИ ИСПОЛЬЗОВАНИЯ НЕТЕПЛОВЫХ НЕИОНИЗИРУЮЩИХ ЭЛЕКТРОМАГНИТНЫХ ПОЛЕЙ}

Электромагнитное загрязнение пространства стало весомым экологическим фактором. Интенсивность техногенных электромагнитных полей значительно превышает фоновые показатели, к которым организмы приспособились в процессе эволюции, в частности своими биоритмами. Накоплено много данных по биологическому воздействию низкоинтенсивных (нетепловых) электромагнитных полей крайне высоких частот (ЭМП КВЧ) на различных уровнях организации. Есть много возможных объяснений такому влиянию, но механизм действия не установлен.

Целью работы является анализ негативных последствий применения нетеплового когерентного электромагнитного миллиметрового излучения. В частности, рассмотрено использование КВЧ-терапии.

Сделан обзор сообщений о пагубных последствиях неионизирующих электромагнитных и магнитных полей среди населения и профессиональных групп, показано существование проблемы гиперчувствительности к таким полям. Приведена информация о развитии направления изучения резонансного биологического воздействия КВЧ-излучения украинскими специалистами.

Особое внимание уделено применению ЭМП КВЧ нетепловой интенсивности для физиотерапевтических процедур, снятия болевого синдрома, коррекции психоэмоциональных нарушений, заживления язв, в частности желудка и двенадцатиперстной кишки и др. Отмечено, что так называемые “лечебные" частоты в случае даже контролируемого воздействия могут вызвать негативные последствия, хотя они и не воспринимаются как повреждающие. Установлены изменения в случае целенаправленного воздействия низкоинтенсивного излучения миллиметрового диапазона объективных показателей жизнедеятельности, а именно: гемодинамики, повышения температуры в зоне воздействия, мышечной активности и скорости прохождения нервного импульса, энцефалограммы. Сформулированы предупреждающие рекомендации на основе научнопрактического опыта применения методов КВЧ-акупунктуры в условиях лечебных учреждений.

Синергическое действие различных воздействий, в частности электромагнитных полей, может быть не непосредственным триггером заболевания, а фрактором нескомпенсированного стресса. Поэтому клинические исследования, проведенные много лет назад, нельзя просто отбросить на основании того, что излучение миллиметрового диапазона проникает только во внешние слои кожи. Клетки кожи также могут выделять медиаторы, которые вызывают изменения в ионных кальциевых каналах и колебания уровня кальция в клетках.

Интерес к этим работам оправдан тем, что сейчас источники монохроматического миллиметрового излучения будут распространяться вместе с новыми системами связи. Риски их биологического действия должны быть учтены при установке излучателей.

Ключевые слова: техногенное электромагнитное излучение; биологическое воздействие; крайне высокочастотная терапия; биологические риски. 